JIPS, Vol. 2 No. 2

Halaman: 245 - 254

Desember 2021

\title{
In House Training sebagai Upaya Peningkatan Kompetensi Literasi IT Guru pada Masa Pandemik di SDN Purwosari 02 Kota Semarang
}

\author{
Anik Kristyanti \\ SDN Purwosari 02 Semarang \\ anikkristyanti67@gmail.com
}

\begin{abstract}
The demanding COVID-19 pandemic period requires teachers to always be alert to various conditions regarding online learning. This is certainly a new phenomenon for teachers and makes a new responsibility for the success of student learning outcomes with the demands of mastering IT on the teacher, but not all teachers including teachers at SDN Purwosari 02 Semarang City have IT literacy competence, many teachers are clueless in doing learning process, so that the learning process uses only one learning, namely WA by sending assignments to students and students sending them back to teachers without any other innovations in the use of Web-based technology, of the 15 teachers at SDN Purwosari 02 Semarang City there are only 6 teachers or 40\% who really have IT literacy. Such a situation certainly requires the role of the principal to improve the IT literacy of teachers by conducting supervision by means of In House Training (IHT). This study is intended to answer the problem: is there an increase in teacher IT literacy competence during the pandemic after the In House Training was held at SDN Purwosari 02 Semarang City in the 2020/2021 Academic Year?. These problems are discussed through classroom action research which is carried out through 2 cycles with each cycle the stages are planning, action, observation and reflection. The results showed that there was an increase in the IT literacy competence of teachers during the pandemic after the In House Training was carried out at SDN Purwosari 02 Semarang City in the 2020/2021 academic year, this can be seen from the increase in the results of teacher professionalism in classroom administration management per cycle where in the first cycle there were 11 teachers or $69 \%$, and in the second cycle there were 15 teachers or $94 \%$. These results indicate that these results are in line with expectations.
\end{abstract}

Keywords: In House Training, Improvement, Competence, IT Literacy, Pandemic Period

\begin{abstract}
ABSTRAK
Masa pandemi covid 19 yang menuntut mengharuskan guru selalu siaga terhadap kondisi yang beragam mengenai pembelajaran daring. Hal tersebut tentunya menjadi fenomena baru bagi guru dan menjadikan tanggung jawab baru bagi kesuksesan hasil belajar peserta didik dengan tuntuan penguasaan IT pada diri guru, Namun tidak semua guru termasuk guru di SDN Purwosari 02 Kota Semarang memiliki kompetensi lietarasi IT, bayak guru yang gaptek dalam melakukan pembelajaran, sehingga proses pembelajaraanya hanya menggunakan satu pembelajran yaitu WA dengan mengirimkan tugas pada siswa dan ssiswa mengirimkan lagi kepad aguru tanpa ada inovasi penggunaan teknologi berbasis Web yang lain, dari 15 guru yang ada di SDN Purwosari 02 Kota Semarang hanya ada 6 guru atau $40 \%$ yang benar-benar memiliki literasi IT. Keadaan demikian tentunya membutuhkan peran kepala sekolah untuk meningkatkan literasi IT guru dengan melakukan supervisi dengan cara In House Training (IHT). Studi ini dimaksudkan untuk menjawab permasalahan: adakah peningkatan kompetensi literasi IT guru pada masa pandemik setelah dilaksanakan In House Training di SDN Purwosari 02 Kota Semarang Tahun Pelajaran 2020/2021?. Permasalahan tersebut di bahas melalui penelitian tindakan kelas yang dilakukan melalui 2 siklus dengan setiap siklus tahapannya adalah perencanaan, tindakan, observasi dan refleksi. Hasil penelitian menunjukkan bahwaterjadi peningkatan kompetensi literasi IT guru pada masa pandemik setelah dilaksanakan In House Training di SDN Purwosari 02 Kota Semarang Tahun Pelajaran 2020/2021, hal ini dapat dilihat dari peningkatan hasil profesionalitas guru dalam pengelolaan administrasi kelas per siklus dimana pada siklus I ada 11 guru atau 69\%, dan pada siklus II sudah mencapai ada 15 guru atau 94\%. Hasil tersebut menunjukkan bahwa hasil tersebut sesuai dengan yang diharapkan.
\end{abstract}

Kata Kunci: In House Training, Peningkatan, Kompetensi, Literasi IT, Masa Pandemik 


\section{PENDAHULUAN}

Penggunaan berbagai cara termasuk pemanfaatan TIK dan kriteria holistik (pengetahuan, keterampilan, dan sikap) diharapkan tidak hanya mengukur apa yang diketahui oleh peserta didik, tetapi lebih menekankan untuk mengukur apa yang dapat dilakukan oleh peserta didik. Pengaplikasian teknologi ke dalam pendidikan dan pembelajaran meru-pakan salah satu bentuk inovasi yang bertujuan untuk mengimbangi dan mengikuti perkembangan zaman (Sudibjo, 2019). Pertimbangan lain yang melatarbelakanginya ialah faktor peserta didik yang jauh berbeda karakteristiknya jika dibandingkan dengan sebelumnya. Siswa kurang lagi tertarik dengan proses pembelajaran yang berpusat pada guru, melainkan lebih tertarik dengan sesuatu hal yang baru dengan berorientasi pada proses penemuan dari mereka sendiri (Setiawan, et.al., 2015).

Namun tidak semua guru termasuk guru di SDN Purwosari 02 Kota Semarang memiliki kompetensi literasi IT, bayak guru yang gaptek dalam melakukan pembelajaran, sehingga proses pembelajaraanya hanya menggunakan satu pembelajran yaitu WA dengan mengirimkan tugas pada siswa dan ssiswa mengirimkan lagi kepad aguru tanpa ada inovasi penggunaan teknologi berbasis Web yang lain, dari 15 guru yang ada di SDN Purwosari 02 Kota Semarang hanya ada 6 guru atau $40 \%$ yang benar-benar memiliki literasi IT .

Keadaan demikian tentunya membutuhkan peran kepala sekolah untuk meningkatkan literasi IT guru dengan melakukan supervisi, salah satunya dengan cara In House Training (IHT). IHT merupakan program pelatihan yang diselenggarakan di tempat sendiri, sebagai upaya untuk meningkatkan kompetensi guru dalam menjalankan pekerjaannya dengan mengoptimalkan potensi-potensi yang ada (Sujoko, 2012: 40).

Berdasarkan latar belakang di atas peneliti tertarik untuk mengadakan penelitian tindakan sekolah tentang "In House Training Sebagai Upaya Peningkatan Kompetensi Literasi IT Guru pada Masa Pandemik di SDN Purwosari 02 Kota Semarang Tahun Pelajaran 2020/2021"

\section{KAJIAN TEORI}

In House Training adalah pelatihan yang dilaksanakan secara internal di kelompok kerja guru, sekolah, atau tempat lain yang ditetapkan untuk menyelenggarakan pelatihan (Danim, 2011: 94). Menurut Sujoko (2012), In House Training merupakan program pelatihan yang diselenggarakan ditempat sendiri, sebagai upaya untuk meningkatkan kompetensi guru, dalam menjalankan pekerjaannya dengan mengoptimalkan potensi-potensi yang ada. 
Menurut Am0065rican Library Association (ALA), literasi informasi adalah serangkaian kemampuan yang dibutuhkan seseorang untuk menyadari kapan informasi dibutuhkan mengevaluasi dan menggunakan informasi secara efektif. Sementara itu, pengertian literasi teknologi menurut SETDA (2017) yaitu kemampuan untuk secara bertanggung jawab menggunakan teknologi yang tepat untuk berkomunikasi, mengakses, mengelola, mengintegrasikan, mengevaluasi, dan membuat informasi.

Tabel 1. Aspek Literasi IT Menurut NDLA

\begin{tabular}{|l|l|}
\hline \multicolumn{1}{|c|}{ Aspek } & \multicolumn{1}{|c|}{ Sub aspek } \\
\hline Keterampilan komputer & $\begin{array}{l}\text { Keterampilan dasar komputer, keterampilan } \\
\text { dasar internet, penggunaan email, Windows } \\
10, \text { Mac OS X } \\
\text { Keterampilan software } \\
\text { Microsoft word, Microsoft excel, Microsoft } \\
\text { powerpoint } \\
\text { Media sosial, literasi informasi } \\
\text { Penggunaan teknologi } \\
\text { dalam kehidupan } \\
\text { sehari-hari }\end{array}$ \\
\hline
\end{tabular}

Literasi IT dapat mempersiapkan anak-anak dan remaja untuk memiliki keterampilan yang mereka butuhkan dalam lingkup teknologi secara aman dan tanggung jawab. Seseorang yang 'melek IT' dapat menggunakan teknologi secara tepat untuk menemukan dan mengevaluasi informasi, terhubung dan berkolaborasi dengan yang lain, menghasilkan dan membagikan konten tanpa menambah dan mengurangi, serta menggunakan TIK sebagai alat untuk mencapai tujuan akademis, profesional (Grech, 2014). Lebih jelasnya peneliti gambarkan dalam bagan berikut:

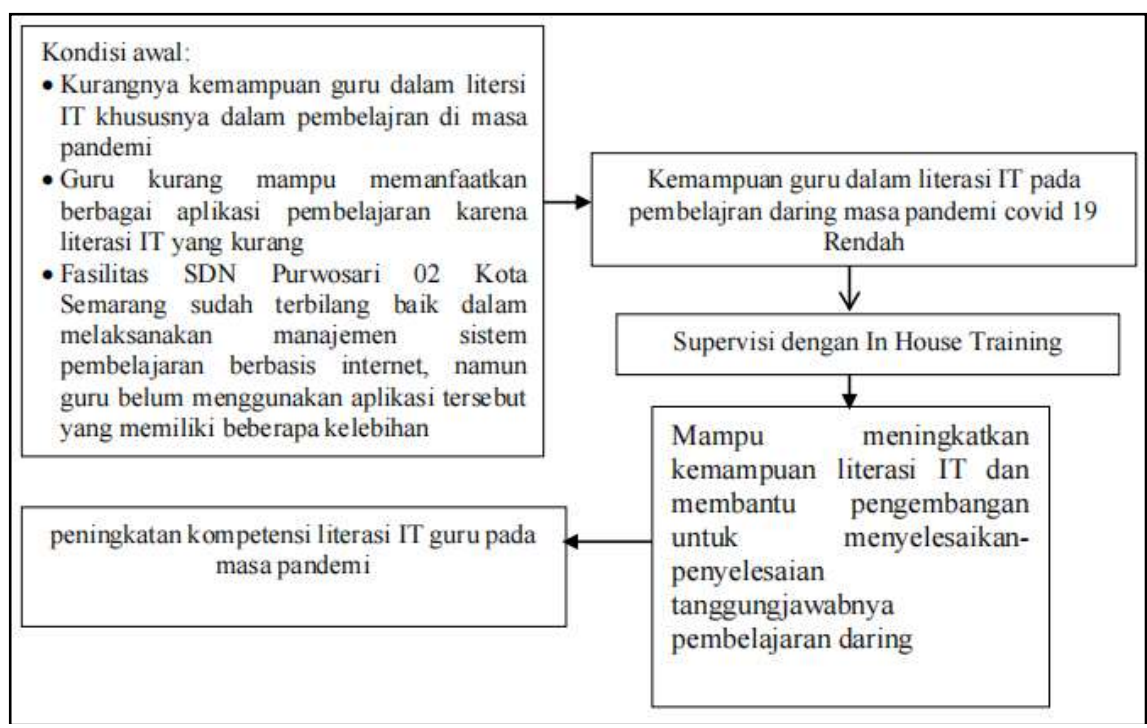

Gambar 1. Kerangka Berpikir 
Hipotesis tindakan dalam penelitian ini adalah terjadi peningkatan kompetensi literasi IT guru pada masa pandemi setelah dilaksanakan In House Training di SDN Purwosari 02 Kota Semarang Tahun Pelajaran 2020/2021.

\section{METODE PENELITIAN}

Tempat penelitian SDN Purwosari 02 Kota Semarang. Penelitian ini dilakukan pada tanggal 19 Januari 2021 sd 27 Maret 2021. Adapun subjek dalam penelitian ini adalah seluruh guru SDN Purwosari 02 Kota Semarang Tahun Pelajaran 2020/2021 sejumlah 16 guru. Variabel penelitian terdiri atas variabel bebas dan variabel terikat. Variabel bebas (yang mempengaruhi) dalam penelitian ini adalah In House Training sedangkan variabel terikatnya (yang dipengaruhi) adalah kompetensi literasi IT guru pada masa pandemik.

Prosedur penelitian yang digunakan peneliti adalah prosedur tindakan Lewin spiral of steps yaitu setiap langkah terdiri atas empat tahap, yaitu perencanaan, tindakan, observasi, dan refleksi. Untuk lebih jelasnya rangkaian ini dapat dilihat pada gambar berikut ini:

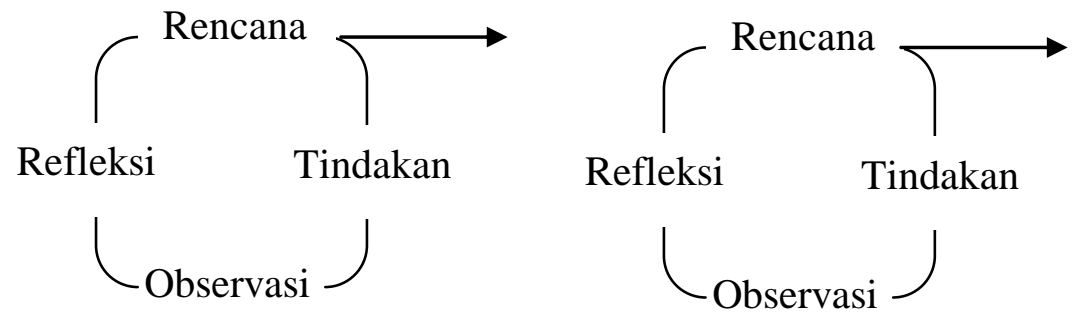

Gambar 3. Desain Penelitian Lewin spiral of steps

Teknik Pengumpulan Data

1. Metode Observasi

2. Metode Dokumentasi

Alat Penilaian

Alat penilaian yang diogunakan peneliti adalah lembar penilaian kemampuan literasi IT guru. Analisis Data

1. Analisis deskriptif kualitatif

2. Analisis kuantitatif

Untuk mengukur persentase keberhasilan guru secara individu menggunakan rumus :

$$
\text { Nilai }=\frac{\text { Skor yang dicapai }}{\text { skor maksimal }} \times 100 \%
$$


Sedangkan untuk mengetahui keberhasilan klasikal atau keseluruhan guru digunakan rumus berikut :

$\mathrm{P}=\frac{\sum n 1}{\sum n 2} x 100 \%$

Keterangan :

$\mathrm{P} \quad$ : Nilai keberhasilan

$\sum n 1 \quad$ Jumlah guru yang berhasil

$\sum n 2$ : Jumlah total guru

Sedangkan Untuk mengetahui tingkat keberhasilan penelitian tindakan sekolah ini apabila terjadi peningkatan peningkatan kompetensi literasi IT guru pada masa pandemik pada kategori baik dan baik sekali sebanyak $90 \%$.

Kriteria:

Baik Sekali (A) $\quad: 90<\mathrm{A} \leq 100$

Baik (B) $\quad: 70<\mathrm{B} \leq 89$

Cukup (C) $\quad: 50<\mathrm{C} \leq 69$

Kurang (K) $\quad: \leq 49$

\section{HASIL PENELITIAN}

\section{Siklus I}

Pelaksanaan siklus I dilakukan pada 19 Januari 2021. Hasil penelitian berdasarkan observasi terhadap literasi IT guru sebagai berikut :

Tabel 1. Kompetensi Literasi IT Guru Siklus I

\begin{tabular}{|c|c|c|c|}
\hline \multirow{2}{*}{ Nilai } & \multicolumn{2}{|c|}{ Siklus I } & \multirow{2}{*}{ Kategori } \\
\cline { 2 - 4 } & Guru & $\%$ & \\
\hline $90 \%-100 \%$ & 4 & $25 \%$ & Baik sekali \\
\hline $70 \%-89 \%$ & 7 & $44 \%$ & Baik \\
\hline $50 \%-69 \%$ & 5 & $31 \%$ & Cukup \\
\hline$<49 \%$ & 0 & $0 \%$ & Kurang \\
\hline Jumlah & 16 & $100 \%$ & \\
\hline
\end{tabular}

Dari tabel di atas dapat diketahui kompetensi literasi IT guru pada masa pandemik pada siklus I dimana pada kategori baik sekali sebanyak 4 guru atau 25\%, kategori baik sebanyak 7 guru atau 44\%, kategori cukup sebanyak 5 guru atau 31\%, kategori kurang tidak ada guru atau $0 \%$. 


\section{Siklus II}

Pelaksanaan siklus II dilakukan pada tanggal 22 Februari 2021 siklus ini dilakukan beberapa tahapan diantaranya:

1. Perencanaan

2. Tindakan

3. Observasi

Hasil penelitian berdasarkan observasi terhadap literasi IT guru sebagai berikut:

Tabel 2. Kompetensi Literasi IT Guru Siklus II

\begin{tabular}{|c|c|c|c|}
\hline \multirow{2}{*}{ Nilai } & \multicolumn{2}{|c|}{ Siklus II } & \multirow{2}{*}{ Kategori } \\
\cline { 2 - 4 } & Guru & $\%$ & \\
\hline $90 \%-100 \%$ & 8 & $50 \%$ & Baik sekali \\
\hline $70 \%-89 \%$ & 7 & $44 \%$ & Baik \\
\hline $50 \%-69 \%$ & 1 & $6 \%$ & Cukup \\
\hline$<49 \%$ & 0 & $0 \%$ & Kurang \\
\hline Jumlah & 16 & $100 \%$ & \\
\hline
\end{tabular}

Dari tabel di atas dapat diketahui kompetensi literasi IT guru pada masa pandemik pada siklus II dimana pada kategori baik sekali sebanyak 8 guru atau 50\%, naik dari pada siklus I yaitu 4 guru atau 25\%, kategori baik sebanyak 7 guru atau $44 \%$, sama dengan pada siklus I yaitu ada 7 guru atau 44\%, kategori cukup sebanyak 1 guru atau $6 \%$ turun dari pada siklus I yaitu 5 guru atau $31 \%$, kategori kurang tidak ada guru atau $0 \%$ sama dengan siklus I yaitu tidak ada guru atau $0 \%$.

Dari penilaian hasil pada siklus II terjadi peningkatan kompetensi literasi IT guru pada masa pandemik setelah dilaksanakan In House Training di SDN Purwosari 02 Kota Semarang Tahun Pelajaran 2020/2021 sebanyak 94\%, ini menunjukkan bahwa peningkatan kompetensi literasi IT guru pada masa pandemik setelah dilaksanakan In House Training di SDN Purwosari 02 Kota Semarang Tahun Pelajaran 2020/2021 sudah baik, maka penelitian tindakan sekolah ini peneliti hentikan.

Berdasarkan hasil penelitian secara keseluruhan terjadi peningkatan kompetensi literasi IT guru pada masa pandemik setelah dilaksanakan In House Training di SDN Purwosari 02 Kota Semarang Tahun Pelajaran 2020/2021 diakhir tindakan siklus II. untuk lebih jelasnya dapat di lihat dalam tabel dan grafik berikut: 
Tabel 3. Perbandingan Kategori Kompetensi Literasi IT Guru Siklus I dan Siklus II

\begin{tabular}{|c|c|c|c|c|c|}
\hline \multirow{2}{*}{ Nilai } & \multicolumn{2}{|c|}{ Siklus I } & \multicolumn{2}{c|}{ Siklus II } & \multirow{2}{*}{ Kategori } \\
\cline { 2 - 5 } & Guru & $\%$ & Guru & $\%$ & \\
\hline $90 \%-100 \%$ & 4 & $25 \%$ & 8 & $50 \%$ & Baik sekali \\
\hline $70 \%-89 \%$ & 7 & $44 \%$ & 7 & $44 \%$ & Baik \\
\hline $50 \%-69 \%$ & 5 & $31 \%$ & 1 & $6 \%$ & Cukup \\
\hline$<49 \%$ & 0 & $0 \%$ & 0 & $0 \%$ & Kurang \\
\hline Jumlah & 16 & $100 \%$ & 16 & $100 \%$ & \\
\hline
\end{tabular}

Temuan dalam penelitian ini menunjukkan bahwa IHT yang dilaksanakan SDN Purwosari 02 Kota Semarang Tahun Pelajaran 2020/2021 berhasil meningkatkan kompetensi literasi IT guru pada masa pandemik. Pada saat kondisi awal hanya $40 \%$ guru atau hanya 6 guru yang memiliki kompetensi literasi IT. Dari data yang sudah dipaparkan di atas tampak pada siklus 1 tingkat ketuntasan mencapai 69\% atau 11 guru dari 16 guru SDN Purwosari 02 Kota Semarang mampu memenuhi Kriteria Ketuntasan Minimal yaitu mencapai kategori baik dan baik sekali, Meskipun capaian ini belum dikatakan berhasil. Baru pada siklus 2 tingkat ketuntasan mencapai 94\% atau 15 guru dari 16 guru SDN Purwosari 02 Kota Semarang mampu memenuhi Kriteria Ketuntasan Minimal yaitu mencapai kategori baik dan baik sekali. Dengan demikian capaian ketuntasan peserta IHT pada siklus ke II ini dikatakan berhasil.

\section{SIMPULAN}

Dari hasil penelitian dan pembahasan dapat diambil kesimpulan bahwa terjadi peningkatan kompetensi literasi IT guru pada masa pandemik setelah dilaksanakan In House Training di SDN Purwosari 02 Kota Semarang Tahun Pelajaran 2020/2021.

\section{SARAN}

Berdasarkan hasil peneliti, maka ini peneliti mengajukan beberapa saran:

1. Bagi kepala sekolah disarankan agar melanjutkan penelitian tindakan sekolah menggunakan model IHT

2. Bagi guru, disarankan mengembangkan kemampuan literasi IT sebagai dasar untuk dapat melaksanakan pembelajaran daring di masa pandemi, dengan terbiasa mengikuti IHT 
3. Bagi peneliti lain yang akan melakukan penelitian lanjutan, disarankan agar melakukan penelitian ulang tentang literasi minimal 2 siklus, dengan harapan hasilnya akan lebih meningkat.

\section{DAFTAR PUSTAKA}

Ali, R., \& Katz, I. R., 2010, Information and Communication Technology Literacy: What Do Businesses Expect and What Do Business Schools Teach?, Princeton: Educational Testing Service

Arikunto, Suharsimi dan Lia Yuliana, 2013, Manajemen Pendidikan, Yogyakarta: Aditya Media

Arikunto, Suharsimi, 2016, Prosedur Penelitian Suatu Pendekatan Praktek, Jakarta: Rineka Cipta

Danim, Sudarwan, 2011, Pengembangan Profesi Guru, Jakarta: Kencana

Daryanto, 2014, Manajemen Diklat, Yogyakarta: Gava Media

Departemen Pendidikan Direktorat Jendral Pendidikan Dasar dan Menengah, 2013, Penelitian Tindakan Kelas, Direktorat Tenaga Kependidikan

Dewi, N.P.S.R., et.al., 2017. Kemampuan Berpikir Kritis dan Keterampilan Proses dalam Pembelajaran Siklus Belajar 7E Berbasis Kearifan Lokal. Jurnal Pendidikan Indonesia, 6(1)

Erstad, O., 2010, Educating the Digital Generation: Exploring Media Literacy for the $21^{\text {st }}$ Century.Nordic Journal of Digital Literacy, 5(1)

ETS Educational Testing Service, 2012, Digital Transformation, A Framework for ICT Literacy. Princeton, NJ: ETS.

Fidyawati, 2013, Efektifitas In House Training dalam Peningkatan Kompetensi Guru, di SMA Laboratorium Percontohan UPI di Bandung, Bandung: Universitas Pendidikan Indonesia.

Fraillon, J., et.al., 2013, International Computer and Information Literacy Study: Assessment framework. Amsterdam: IEA

Grech, A., 2014, Malta National Lifelong Learning Strategy 2020 Hicks and Turner, diunduh dihttp://www.ncte.org/library/nctefiles/resources/journals/ej/1026-jul2013/ej1026longer.pdf

Hartatik, Indah Puji, 2014, Mengembangkan SDM, Jogjakarta: Laksana

Heldy, Ariston, 2011, Meningkatkan Kemampuan Guru dalam Membuat Power point melalui in House Training di SMK Teknik Industri Purwakarta

Kemaludin, Lulu, 2011, Pengertian In House Training, tujuan dan Manfaatnya. http://tikettraining.com/pengertian-in-house-training-tujuan-dan-manfaatnya 
Kemendikbud, 2017, Buku Guru Ilmu Pengetahuan Alam Kelas VIII, Jakarta: Kemendikbud.

Kong, S.C., 2014. Developing Information Literacy and Critical Thinking Skills through Domain Knowledge Learning in Digital Classrooms: An Experience of Practicing Flipped Classroom Strategy, Computers\& Education, (78)1

Mangkunegara, Anwar Prabu, 2011, Manajemen Sumber Daya Manusia Perusahaan, Bandung: Rosdakarya

Margono, S., 2016, Metodologi Penelitian Pendidikan, Jakarta: Rineka Cipta

Mawansyah, 2010, Manajemen Sumber Daya Manusia, Bandung: Alfabeta

Meldona, 2009, Manajemen Sumber Daya Manusia, Malang: UIN Malang Press.

Nawawi, H. 2017. Manajemen Sumber Daya Manusia, Yogyakarta: Gajah Mada Universitas Press.

Nugroho, Maris Setiyo, 2015, Keefektifan In house training Pekerja Beton Dalam Meningkatkan Kompetensi Profesional Guru Teknik Bangunan SMK Negeri 2 Pengasih, Yogyakarta: Universitas Negeri Yogyakarta

Nurahman, N.I., et.al., 2020. Analysis of Communication Skills and Empathy of Fifth-Grade Students of Elementary Schools through ICT-based Learning. Journal of Primary Education, 9(3)

SETDA The State Educational Technology Directors Association, 2007, Technology Literacy Assessment and Educational Technology Standards Report. MarylandUSA: SETDA

Setiawan, H., et.al., (2015). Implementation of Digital Learning Using Interactive Multimedia in Excretory System with Virtual Laboratory. Research and Evaluation in Education,1(2)

Shakoor, A., et.al., 2013, Effect of In Service Training on the Working Capacity and Performance of Science Teachers at Secondary Level. Jurnal of Educational and Sosial Research MCSER Publishing, Rome-Italy, 3(3)

Sofyandi, Herman, 2018, Manajemen Sumberdaya Manusia, Yogyakarta: Graha Ilmu

Solikhan, 2020, Implementasi In House Training untuk Meningkatkan Kemampuan Guru dalam Menetapkan Kriteria Ketuntasan Minimal, Jurnal Pendidikan: Riset \& Konseptual, 4(2)

Sudibjo, A., 2019. Penggunaan Media Pembelajaran IPA Berbasis Google Classroom pada Materi Alat Optik untuk Meningkatkan Respons Motivasi dan Hasil Belajar Siswa di SMP Negeri 4 Surabaya. Jurnal Education and Development, 7(3)

Sugiyono, 2017, Metodelogi Penelitian Pendidikan Pendekatan Kuantitatif, Kualitatif dan $R \& D$ Bandung : Alfabeta

Sujoko, Alfaris, 2012. Peningkatan Kemampuan Guru Mata Pelajaran Melalui In House Training. Jurnal Pendidikan Penabur No 18 Tahun ke-11 Juni 
Suwatno dkk, 2016, Manajemen SDM dalam Organisasi Publik dan Bisnis, Bandung: Alfabeta

Tarigan, T.P.E., 2019, Menyikapi Era Digital Dalam Pembelajaran Pak, Jurnal Penelitian Fisikawan 2(2) Edisi Agustus

Winarni, E.W., et.al., 2016, Implementasi Pembelajaran Tematik Berbasis ICT untuk Penanaman Sikap, Pengetahuan, dan Keterampilan Peduli Lingkungan bagi Siswa Sekolah Dasar Kota Bengkulu.Dharma RaflesiaUnib, 14(2), Retrieved from https://ejournal.unib.ac.id/ index.php/dharmaraflesia/article/view/4313/2387 